\title{
Erratum on: Epoxyeicosatrienoic acid analog attenuates angiotensin II hypertension and kidney injury
}

\section{Frontiers Production Office *}

Frontiers Production Office, Lausanne, Switzerland

*Correspondence: production.office@frontiersin.org

Approved by:

Pharmacology Editorial Office, Frontiers, Switzerland

Keywords: epoxyeicosatrienoic acid analog, mesenteric artery, endothelial function, renal inflammation, angiotensin II

\section{An erratum on}

Epoxyeicosatrienoic acid analog attenuates angiotensin II hypertension and kidney injury

by Hye Khan, M. A., Falck, J. R., Manthati, V. L., Campbell, W. B., and Imig, J. D. (2014). Front. Pharmacol. 5:216. doi: 10.3389/fphar.2014.00216

Reason for erratum:

The name for the author Md. Abdul Hye Khan was listed as Abdul Hye Khan and the citation as Khan, $\mathrm{AH}$ instead of Hye Khan, MA, due to a typesetting error. This mistake does not change the scientific conclusions of the article in any way. The publisher apologizes for this error.

The original article has been updated.

Received: 27 October 2014; accepted: 27 October 2014; published online: 19 November 2014.

Citation: Frontiers Production Office (2014) Erratum on: Epoxyeicosatrienoic acid analog attenuates angiotensin II hypertension and kidney injury. Front. Pharmacol. 5:250. doi: 10.3389/fphar.2014.00250

This article was submitted to Experimental Pharmacology and Drug Discovery, a section of the journal Frontiers in Pharmacology.

Copyright (c) 2014 Frontiers Production Office. This is an open-access article distributed under the terms of the Creative Commons Attribution License (CC BY). The use, distribution or reproduction in other forums is permitted, provided the original author(s) or licensor are credited and that the original publication in this journal is cited, in accordance with accepted academic practice. No use, distribution or reproduction is permitted which does not comply with these terms. 